\title{
A Review on Applications of Kenaf Fibre Reinforced Composites
}

\author{
Sasikumar Gnanasekaran ${ }^{1}$ and Sivasangari Ayyappan ${ }^{2}$ \\ ${ }^{1}$ Professor and Head, Department of Power Engineering, \\ ${ }^{2}$ Assistant Professor, Department of Electronics and Communication Engineering, \\ GMR Institute of Technology, Srikakulam, Andhra Pradesh, India \\ E-Mail: sivasangari.a@gmrit.org, gsasi78@gmail.com
}

\begin{abstract}
Natural fibres namely sisal, jute, kenaf, hemp, abaca and banana are mainly used in industries for developing Natural fibres composites. They find many applications such as automobiles, furniture, packing and construction due to many merits such as their low cost, good mechanical properties, non-toxic, low weight, less damage to processing equipment, improved surface finish, abundant and renewable resources. The objective of this paper is to review the applications of various kenaf fibre reinforced polymer composites which will provide a base for further research in this area.

Keywords: Natural Fibres, Kenaf Fibre, Natural Fibres Composites
\end{abstract}

\section{INTRODUCTION}

Kenaf is found to be one of the natural fibers used as reinforcement in Polymer Matrix Composites (PMCs) and it is an important source of fiber for composites applications. Kenaf is considered as a cellulosic source which has both economic and ecological advantages. It will be able to grow under different weather conditions with growing speed of $10 \mathrm{~cm} /$ day under optimum ambient conditions. The kenaf plant is composed of many useful components such as stalks, leaves, and seeds. The yield and composition of these plant components are affected by cultivar, planting date, photosensitivity, length of growing season, plant populations, and plant maturity. Kenaf fibre consists of main cellulose $(45-57 \%)$, hemicelluloses $(21.5 \%)$, lignin (8$13 \mathrm{wt} \%)$, pectin $(3-5 \mathrm{wt} \%)$ and waxy substances. Its excellent fiber strength, kenaf fiber has great potential for use in industrial nonwoven materials and for competing with flax and hemp fibers. The kenaf bast fiber is known to have the potential as a reinforcing fiber in thermoplastic composites because of its superior toughness and high aspect ratio in comparison to other fibre [Akil, H.M et al, 2011].

The following are the salient properties of kenaf:

1. high rate of absorption of carbon dioxide from the air by Kenaf plant

2. high rate of absorption of nitrogen and phosphorous by Kenaf plant from the soil

3. Kenaf can be easily recycled

\section{APPLICATIONS OF KENAF FIBRE REINFORCED COMPOSITES}

The polymer based components are utilized from house hold services to space applications. It is the known fact that the usage of polymers cannot be replaced all of a sudden but can be decreased to some percentage in order to reduce the disposal problem. Likewise, the synthetic fibers especially glass fiber have huge threat to the environment and to the health of the workers. In order to replace them, currently researches focus on the natural fibers and their feasibility as the reinforcement in the polymer matrix. Natural fibers, an environmental friendly, low cost, available in abundance and good weight - strength property made them as a suitable alternate to glass fiber (Ishak et al., 2010).

Natural fibers are extracted from various parts of the plant (stem, leaf and bark) and classified accordingly. The most widely used plant fibers include sisal, banana, kenaf, coir etc. Kenaf (Hibiscus Cannabinus L) belongs to the family of hibiscus, a biodegradable and Environmental friendly crop.

Anuar et al. (2008) discussed about optimum processing parameters of Thermo plastic natural rubber (TPNR) hybrid composites with kenaf and glass fiber. In this work, the effect of fiber loading and fiber volume fraction were also studied. The result of tensile strength showed that increasing kenaf fiber content noticeably reduced the tensile strength and modulus. The effect of fiber loading and different fiber volume fractions were also discussed. The effects of coupling agents, silane, and MAPP on tensile properties were also elaborated.

Akil et al. (2011) studied the mechanical, thermal and water absorption properties of kenaf fiber reinforced composites. Moreover, the manufacturing process and their technical issues were also addressed. They have studied improvements made in kenaf fiber reinforced composites research.

Symington et al. (2009) studied the tensile properties of kenaf fibers for structural application. The study revealed that the alkalization will improve the properties of the fiber. John et al. (2010) developed Kenaf-polypropylene composites with zein as a coupling agent to compare the reinforcing properties of the chemically treated composites with that of untreated composites. Composites were prepared by compression moulding using nonwovens treated with zein solution. They found that the mechanical and viscoelastic properties were enhanced by the proposed composites containing chemically modified kenaf fibres. 
Ishak et al. (2010) used kenaf fiber as reinforcement in biocomposite material. The objective was to compare the mechanical properties of short kenaf bast and core fiber reinforced unsaturated polyester composites with varying fiber weight fraction i.e. $0 \%, 5 \%, 10 \%, 20 \%, 30 \%$ and $40 \%$. The results also showed that the optimum fiber content for achieving highest tensile strength for both bast and core fibre composites were $20 \% \mathrm{wt}$.

Bernard et al. (2011) studied the effect of processing parameters on the mechanical properties of kenaf fibre plastic composite. The processing parameters such as temperature and speed were taken in to account. Compression moulding technique was used to fabricate the composite material with Polypropylene (PP) as a binding material. Tensile and impact tests were performed on the developed composite to characterise its mechanical properties. The tensile properties of composite increased by $10 \%$ after the addition of unidirectional kenaf fibre (UKF). However, its impact properties simultaneously deteriorated.

Islam et al. (2011) developed Natural fibre/polypropylene thermoplastic composites produced by compression moulding of a blended preform of polypropylene fibre and natural fibre treated by enzymes. Two preform processing routes were considered: (a) Pre-treatment: treating the natural fibre first and then blending it with the polypropylene fibre and (b) Post treatment: forming a blended preform of the natural fibre and polypropylene fibre first and then carrying out the chemical/enzyme treatment on the blended preform. The composites produced by posttreatment show up to $36 \%$ higher flexural strength and up to $63 \%$ higher flexural modulus than that of pre-treatment route.

Nosbi et al. (2010) developed a pultruded kenaf fiber reinforced unsaturated polyester composites to study water absorption behavior with minimum kenaf fiber content of $70 \%$ w/w. Residual compressive properties of the composites after immersion were also reported. Water absorption tests were performed at room temperature under three different solutions, i.e. distilled water, sea water and acidic solution.

Rassmann et al. (2010) studied the effects of processing conditions on the mechanical and water absorption properties of resin transfer moulded kenaf fibre reinforced polyester composite laminates. Laminates were produced by changing fibre moisture content, mould temperature and mould pressure following injection. Tensile, flexural, impact and water absorption tests were conducted to analyse the properties of the composite at different processing conditions.

Ghani et al. (2012) investigated the mechanical properties of Kenaf fiber/fiberglass reinforced with unsaturated polyester composites subjected to water absorption test. Water absorption test were conducted by immersing specimens into three different environmental conditions. In general, the mechanical properties of kenaf fiber are deteriorated after the moisture penetrates into the composite.

Md. Akil et al. (2010) studied the flexural and indentation behaviour of pultruded jute/glass and kenaf/glass hybrid composites monitored using acoustic emission which were compared with that of kenaf fiber composites.

Salleh et al. (2013) developed long kenaf composites and long kenaf/woven glass reinforced polyester resin composites. The tensile properties of those composites with drilled holes were investigated. It is found that the long kenaf composite was more notch sensitive than long kenaf/woven glass hybrid composite.

Tajeddin et al. (2010) studied the effect of polyethylene glycol on the characteristics of kenaf cellulose (KC) /lowdensity polyethylene (LDPE) biocomposites. Different weights of LDPE, KC, and PEG were mixed, the effects of varying the concentrations of $\mathrm{KC}$ and PEG on the synthesis process were evaluated, and the resulting composites were characterized with respect to their mechanical, thermal, biodegradability and water-absorption properties.

Batouli et al. (2014) examined the environmental performance of kenaf-fiber reinforced polyurethane by using a life cycle assessment approach for structural insulated panels fabrication. Three composites made of rigid polyurethane (PU) reinforced with 5, 10 and $15 \%$ kenaf core were prepared and analyzed. The three composites and pure rigid polyurethane were then used as insulation cores of SIPs with the same kenaf-based structural boards. A life cycle assessment (LCA) was conducted to determine the environmental profiles of the four SIPs in 10 a nd $50^{\circ}$ Celsius. Their findings suggest that fabrication methods are critical to maintain optimal thermal and structural characteristics of composites without scarifying their environmental performance.

Zamri Yusoff et al. (2015) discussed the variety of the extensive research efforts on the kenaf reinforced composites. El-Shekeil et al. (2014) studied the influence of fiber content on mechanical, morphological and thermal properties of kenaf fibers reinforced polyvinyl chloride /thermoplastic polyurethane poly-blend composites. Hafizah et al. (2014) conducted an experimental study to investigate structural behaviour of RC beams strengthened by kenaffiber reinforced polymer composite.

\section{CONCLUSION}

The paper is intended to present the various salient points of the research works reported on Kenaf Fibre reinforced composites based on the literature survey. Many Kenaf Fibre reinforced composites are being developed by researchers for various industrial applications due to their mechanical, thermal and water absorption properties. In this paper, the control variables such as fibre length, fibre treatment, fibre orientation, resins, proportion of mix, 
fabrication methods, etc., were discussed for various applications. It is believed that there would be lot of scope for active research on Kenaf Fibre reinforced composites, particularly in structural applications taking in to account the lightweight and low cost.

\section{REFERENCES}

[1] H. Anuar, and A. Zuraida, "Improvement in mechanical properties of reinforced thermoplastic elastomer composite with kenaf bast fibre", Composites Part B: Engineering, Vol. 42, pp. 462-465, 2011.

[2] H.M. Akil, M.F. Omar, A.A.M. Mazuki, S. Safiee, Z.A.M. Ishak, and A. Bakar, "Kenaf fiber reinforced composites", Materials \& Design, Vol. 32, pp. 4107-4121, 2011.

[3] S. M. Batouli, Y. Zhu, M. Nar, and N. A. D'Souza, "Environmental performance of kenaf-fiber reinforced polyurethane: a life cycle assessment approach", Journal of Cleaner Production, Vol. 66, pp. 164-173, 1 March 2014.

[4] M. Bernard, A. Khalina, A. Ali, R. Janius, M. Faizal, K.S. Hasnah, and A.B. Sanuddin, "The effect of processing parameters on the mechanical properties of kenaf fibre plastic composite", Materials \& Design, Vol. 32, pp. 1039-1043, 2011.

[5] Y. A. El-Shekeil, Sapuan, S. M. Jawaid, M. Al-Shuja'a, O. M. "Influence of fiber content on mechanical, morphological and thermal properties of kenaf fibers reinforced poly(vinyl chloride)/thermoplastic polyurethane poly-blend composites", Materials \& Design, Vol. 58, pp. 130-135, 2014

[6] M.A.A. Ghani, Z. Salleh, K.M. Hyie, M.N. Berhan, Y.M.D. Taib, and M.A.I. Bakri, "Mechanical Properties of Kenaf/Fiberglass Polyester Hybrid Composite", Procedia Engineering, Vol. 41, pp. 1654-1659, 2012.

[7] N.A.K. Hafizah, M.A.R. Bhutta, M.Y. Jamaludin, M.H.Warid, M.Ismail, M.S.Rahman, I.Yunus and M.Azman, "Kenaf Fibre Reinforced Polymer Composites for strengthening RC Beams, Journal of Advanced Concrete Technology, V ol. 12, pp. 167-177, 2014.

[8] M.R. Ishak, Z. Leman, S.M. Sapuan, A.M.M. Edeerozey and I.S. Othman, Mechanical properties of kenaf bast and core fibre reinforced unsaturated polyester composites, IOP Publishing Ltd. 2010 .

[9] M.S. Islam, J.S. Church, and M. Miao, "Effect of removing polypropylene fibre surface finishes on mechanical performance of kenaf/polypropylene composites", Composites Part A: Applied Science and Manufacturing, Vol. 42, pp. 1687-1693, 2011.

[10] M. J. John, C. Bellmann, and R. D. Anandjiwala, "Kenafpolypropylene composites: Effect of amphiphilic coupling agent on surface properties of fibres and composites", Carbohydrate Polymers, Vol. 82, No. 3, pp. 549-554, 2010.

[11] H. Md. Akil, I.M.D. Rosa, C. Santulli, F. Sarasini, Flexural behaviour of pultruded jute/glass and kenaf/glass hybrid composites monitored using acoustic emission. Materials Science and Engineering: A, Vol. 527, pp. 2942-2950, 2010.

[12] N. Nosbi, H. M. Akil, Z. A. Mohd Ishak, and A. Abu Bakar, "Degradation of compressive properties of pultruded kenaf fiber reinforced composites after immersion in various solutions", Materials \& Design, Vol. 31, pp. 4960-4964, 2010.

[13] S. Rassmann, R.G. Reid, and R. Paskaramoorthy, "Effects of processing conditions on the mechanical and water absorption properties of resin transfer moulded kenaf fibre reinforced polyester composite laminates", Composites Part A: Applied Science and Manufacturing, Vol. 41, pp. 1612-1619, 2010.

[14] B. Tajeddin, R.A. Rahman, and L.C. Abdulah, "The effect of polyethylene glycol on the characteristics of kenaf cellulose/lowdensity polyethylene biocomposites", International Journal of Biological Macromolecules, Vol. 47, pp. 292-297, 2010.

[15] Z. Salleh, M. N. Berhan, K. M. Hyie, Y. M.Taib, A. Kalam, and N. R. Nik Roselina, "Open Hole Tensile Properties of Kenaf Composite and Kenaf/Fibreglass Hybrid Composite Laminates", Procedia Engineering, Vol. 68, pp. 399-404, 2013.

[16] M. C. Symington, W. M. Banks and O. D. West, "Tensile testing of cellulose based natural fibers for structural composite application", Journal of Composite Materials, Vol. 43, No. 9, pp. 1083-108, 2009.

[17] Zamri Yusoff and Zaukafli Mohamad, "Review of Research Activities on Kenaf Reinforced Composites", Journal of Petrochemical Engineering Department, Vol.1, No. 1, pp. 25-33, 2015. 